\title{
Pengembangan Sistem Pakar sebagai Bahan Ajar dalam Pembelajaran Fisiologi Hewan sub Materi Fisiologi Sirkulasi
}

\author{
Hudiana Hernawan ${ }^{\# 1}$, Purnomo Sidiq ${ }^{* 2}$ \\ ${ }^{\# 1}$ Program Studi Pendidikan Biologi, STKIP Garut \\ Jl. Pahlawan no 32 Sukagalih kode pos 44151 Garut \\ 1'hudianahernawan62@gmail.com \\ ${ }^{* 2}$ Program Studi Pendidikan Teknologi Informasi, STKIP Garut \\ Jl. Pahlawan no 32 Sukagalih kode pos 44151 Garut
}

22purnomosidiq.ps@gmail.com

Abstract - Rendahnya mutu pendidikan di Indonesia salah satu penyebabnya adalah minimnya sumber bahan ajar yang dapat dimanfaatkan, baik oleh mahasiswa maupun dosen. Bahan ajar yang tersedia saat ini masih konvensional dan belum dapat meningkatkan minat dan motivasi mahasiswa untuk mempelajarinya. Disamping itu, metode pembelajaran yang dipergunakan selama ini masih menggunakan metode konvensional. Kondisi ini akan membuat kesulitan dan ketidakmandirian mahasiwa yang pada gilirannya akan menyebabkan rendahnya mutu pendidikan. Bahan ajar yang tersedia saat ini masih konvensional dan belum dapat meningkatkan minat belajar mahasiswa. Tersedianya sumber belajar yang ekonomis, praktis dan sederhana, fleksibel, relevan, dan memiliki nilai positif akan mendukung kegiatan pembelajaran yang lebih efektif serta memudahkan mencapai tujuan pembelajaran. Salah satu alternatif pemecahan masalah ini adalah dengan memanfaatkan Teknologi Informasi. Teknologi informasi (Information Technology) meliputi segala hal yang berkaitan dengan proses, penggunaan sebagai alat bantu, manipulasi, dan pengelolaan informasi yang menggabungkan komputasi komputer dengan jalur komunikasi berkecepatan tinggi yang membawa data, suara, dan gambar. Salah satu produk Teknologi Informasi, yaitu aplikasi Sistem Pakar. Produk ini dapat mengintegrasikan antara teknologi komputer dengan pembelajaran, tidak hanya tekstual tapi juga visual. Tujuan dari penelitian ini untuk merancang dan mengembangkan Sistem Pakar, sedangkan manfaat yang diharapkan dapat dijadikan salah satu alternatif dalam penyediaan bahan ajar Fisiologi Hewan. Penelitian ini merupakan penelitian Research and Development yang terdiri atas dua tahapan, yaitu proses pengembangan Sistem Pakar dan analisis produk. Hasil uji validasi produk, menurut ahli media dan ahli materi secara umum aspek produk penelitian yang dikembangkan sudah layak. Sedangkan validasi pengguna, secara umum mahasiswa sangat senang, mudah memahami, dan mudah mengoperasikan Sistem Pakar. Tanggapan mahasiswa terhadap produk Sistem Pakar untuk kategori Quality of end-user interface design termasuk dalam kriteria baik (56,24\%), kategori Engagement termasuk dalam kriteria sangat baik $(64,90 \%)$, kategori Interactivity termasuk dalam kategori sangat baik $(63,90 \%)$, dan kategori Tailorability termasuk dalam kriteria baik $(52,29 \%)$. Secara keseluruhan, hasil penelitian menunjukkan bahwa Sistem Pakar dapat diterapkan dan layak digunakan sebagai media pembelajaran untuk mahasiswa Pendidikan Biologi.

Keywords - Fisiologi Hewan, Fisiologi Sirkulasi, Sistem Pakar, Teknologi Informasi

\section{Pendahuluan}

Seperti diketahui, pendidikan merupakan suatu upaya meningkatkan kualitas manusia secara menyeluruh meliputi aspek pengetahuan, keterampilan, sikap, dan nilai-nilai. Pengembangan aspek-aspek tersebut dilakukan untuk meningkatkan dan mengembangkan kecakapan hidup (life skill) melalui seperangkat kompetisi, agar siswa dapat bertahan hidup, menyesuaikan dan berhasil dalam kehidupannya di masa yang akan datang. Hal ini sesuai dengan Tujuan Pendidikan Nasional seperti yang tercantum dalam Undang-Undang Sistem Pendidikan Nasional Bab II pasal 3 sebagai berikut: Pendidikan Nasional bertujuan mencerdaskan kehidupan bangsa dan bertakwa terhadap Tuhan Yang Maha Esa dan berbudi pekerti luhur, memiliki pengetahuan dan keterampilan, kesehatan jasmani dan rohani, kepribadian yang mantap dan mandiri serta rasa tanggung jawab kemasyarakatan dan kebangsaan.

Untuk mencapai tujuan pendidikan nasional tersebut perlu dilakukan berbagai upaya agar proses pembelajaran berjalan sesuai dengan yang diharapkan. Upaya yang perlu dilakukan oleh dosen adalah dengan meningkatkan kompetensinya, sehingga materi pembelajaran yang 
disampaikan dapat dimengerti dan dipahami oleh mahasiswa. Sedangkan upaya yang perlu dilakukan oleh mahasiswa adalah dengan meningkatkan kualitas belajarnya sehingga materi yang disampaikan oleh dosen dapat diserap dengan baik.

Secara umum, mahasiswa program pendidikan Biologi merasa sulit belajar materi Fisiologi Sirkulasi, sehingga banyak mahasiswa kurang tertarik untuk mempelajarinya. Hal ini disebabkan oleh beberapa aspek antara lain: kompleksitas materi dan model pembelajaran di kelas. Model pembelajaran yang secara umum digunakan dosen dalam pembelajaran adalah model klasikal dalam bentuk ceramah. Pembelajaran yang demikian biasanya menjadikan mahasiswa kurang memahami dan kurang mandiri karena terlalu mengandalkan penjelasan dosen. Menurut Kusuma (2011:49), belajar mandiri tidak berarti belajar sendiri. Hal yang terpenting dalam proses belajar mandiri adalah peningkatan kemauan dan keterampilan mahasiswa dalam proses belajar tanpa bantuan orang lain, sehingga mereka tidak bergantung pada dosen, teman, atau orang lain dalam belajar. Proses belajar mandiri memberi kesempatan mahasiswa untuk mencerna materi ajar dengan sedikit bantuan dosen. Mereka mengikuti kegiatan belajar dengan materi ajar yang sudah dirancang khusus sehingga masalah atau kesulitan belajar sudah diantisipasi sebelumnya.

Kesulitan dan ketidakmandirian mahasiwa pada gilirannya akan menyebabkan rendahnya mutu pendidikan. Salah satu penyebabnya adalah minimnya bahan ajar yang dapat dimanfaatkan, baik oleh mahasiswa maupun dosen. Bahan ajar yang tersedia saat ini masih konvensional dan belum dapat meningkatkan minat belajar mahasiswa. Tersedianya sumber belajar yang ekonomis, praktis dan sederhana, fleksibel, relevan, dan memiliki nilai positif akan mendukung kegiatan pembelajaran yang lebih efektif serta memudahkan mencapai tujuan pembelajaran (Rohani, 2004).

Untuk mengatasi kendala-kendala dalam pembelajaran yang masih konvensional dan minimnya bahan ajar yang tersedia, perlu dikembangkan bahan pembelajaran yang memperhatikan kemampuan mahasiswa, mendukung pembelajaran perseorangan dan mandiri, serta dapat memudahkan belajar mahasiswa. Menurut Dick dan Carey (1990:72), bahan pembelajaran hendaknya merupakan bahan yang seluruhnya dapat dipelajari sendiri oleh peserta didik. Maksudnya, bahan tersebut dapat memberikan kesempatan pada mahasiswa untuk mempelajarinya tanpa bergantung pada penjelasan dosen. Oleh karena itu, pembelajaran yang baik juga akan mengaktifkan mahasiswa dalam memberikan tanggapan, umpan balik, dan juga mendorong mahasiswa untuk melakukan praktik-praktik dengan benar. Dengan demikian, mengemas bahan ajar secara tersusun dan berkualitas sangat penting dalam meningkatkan kualitas proses pembelajaran. Oleh karena itu, bahan ajar merupakan unsur yang menentukan keberhasilan mahasiswa belajar.
Salah satu alternatif pemecahan masalah di atas, yaitu dengan memanfaatkan kemajuan Teknologi Informasi. Teknologi informasi (Information Technology) meliputi segala hal yang berkaitan dengan proses, penggunaan sebagai alat bantu, manipulasi, dan pengelolaan informasi. Pengertian teknologi informasi adalah suatu teknologi yang digunakan untuk mengolah, memproses, mendapatkan, menyusun, menyimpan, memanipulasi data dalam berbagai cara untuk menghasilkan informasi yang berkualitas Wardiana (dalam Warsita, 2008). Teknologi informasi adalah teknologi yang menggabungkan komputasi komputer dengan jalur komunikasi berkecepatan tinggi yang membawa data, suara, dan video.

Kecenderungan teknologi informasi mengarah pada pemanfaatan teknologi komputer dan teknologi terkait dalam mengintegrasikan suatu data, gambar, grafik dan suara sehingga menghasilkan suatu informasi secara komprehensif. Berbagai perkembangan pemahaman tentang media terus berkembang seiring dengan perkembangan Teknologi Informasi dan Komunikasi untuk aspek software maupun hardware yang mendukungnya (Darmawan, 2015: 31).

Produk Teknologi Informasi yang dapat dijadikan media pelengkap dan sarana belajar adalah Sistem Pakar. Sistem Pakar merupakan multimedia yang berisikan informasi digital yang berwujud teks, gambar, dan lain-lain yang merupakan representasi elektronik berbentuk digital (Lee, 2004 dalam Darmawan, 2011) yang dapat memfasilitasi kebutuhan peserta didik, tidak hanya tekstual tetapi juga audio dan visual (Munir, 2010).

Sistem Pakar adalah produk teknologi informasi yang merupakan suatu bentuk sistem yang berusaha mengadopsi ilmu pengetahuan manusia dan diaplikasikan dalam komputer, sehingga komputer memiliki kemampuan dalam menyelesaikan masalah seperti yang dilakukan oleh seorang ahli.

Definisi tentang sistem pakar (Kusumadewi, 2003), antara lain: menurut Durkin: Sistem Pakar adalah suatu program komputer yang dirancang untuk memodelkan kemampuan penyelesaian masalah yang dilakukan oleh seorang pakar. Adapun knowledge atau ilmu pengetahuan dalam sistem pakar mungkin saja seorang ahli atau pakar, atau ilmu pengetahuan (knowlegde) yang umumnya terdapat dalam buku, majalah, dan orang yang mempunyai pengetahuan tentang suatu bidang (Arhami, 2005).

Turban (1995) berpendapat bahwa konsep dasar sistem pakar mengandung keahlian, ahli, pengalihan, inferensi, aturan dan kemampuan menjelaskan. Keahlian adalah suatu kelebihan penguasaan pengetahuan di bidang tertentu yang diperoleh dari pelatihan, membaca, atau pengalaman (Arhami, 2005).

Kemampuan keahlian dari para ahli ke komputer untuk kemudian dialihkan lagi ke orang lain yang bukan ahli, merupakan tujuan dari Sistem Pakar. Adapun proses terbentuknya Sistem Pakar membutuhkan empat aktivitas, 
yaitu: tambahan pengetahuan (dari para ahli atau sumbersumber lainnya), representasi pengetahuan ke komputer, inferensi pengetahuan, dan pengalihan pengetahuan ke pengguna (Arhami, 2005).

Gambar 1 di bawah, merupakan gambaran konsep dasar Sistem Pakar, dimana pengguna (user) menyampaikan fakta atau informasi kepada Sistem Pakar, kemudian fakta dan informasi tersebut akan di simpan ke knowledge-base (basis pengetahuan), dan diolah dengan mekanisme inferensi, sehingga sistem dapat memberikan respon kepada penggunanya berupa keahlian atau jawaban berdasarkan pengetahuan yang dimilikinya (Kaur, 2014).

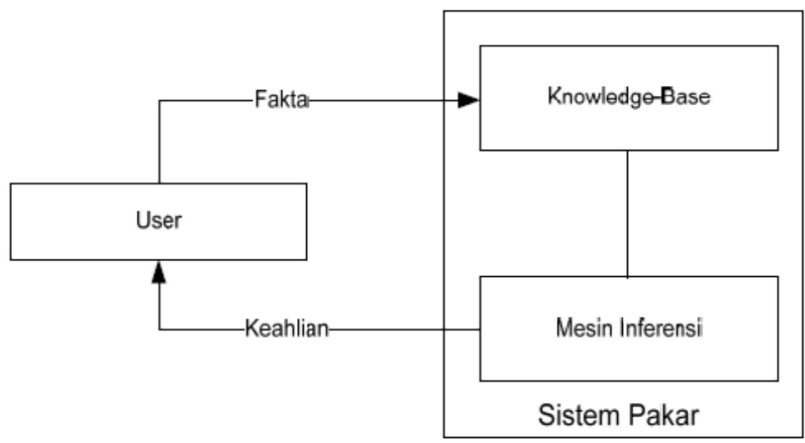

Gambar 1. Konsep dasar Sistem Pakar

Pada pengembangan sistem pakar diperlukan beberapa tahapan agar dapat menghasilkan suatu sistem yang berhubungan hingga suatu sistem terwujud. Tahapantahapan tersebut dapat dilihat pada gambar berikut ini:

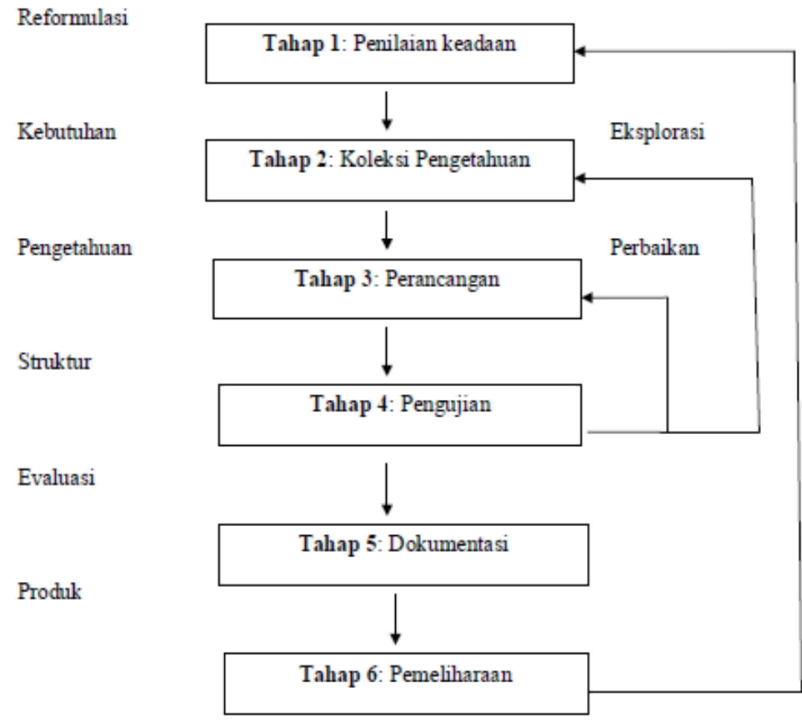

Gambar 1. Tahapan produksi Sistem Pakar

Tujuan dari sebuah Sistem Pakar adalah mentransfer kepakaran yang dimiliki seorang pakar ke dalam komputer dan kemudian kepada orang lain (non expert). Aktivitas pemindahan kepakaran adalah : Knowledge Acquisition (dari pakar atau sumber lain); Knowledge Representation (ke dalam komputer); Knowledge Inferencing; dan
Knowledge Transfering.

Knowledge base adalah representasi pengetahuan dari seorang atau beberapa pakar yang diperlukan untuk memahami, memformulasikan dan memecahkan masalah. Dalam hal ini digunakan untuk memecahkan masalahmasalah yang terjadi pada komputer. Knowledge base ini terdiri dari dua elemen dasar, yaitu fakta dan rules. Inference engine merupakan otak dari sistem pakar yang mengandung mekanisme fungsi berpikir dan pola-pola penalaran sistem yang digunakan oleh seorang pakar. Mekanisme ini yang menganalisis suatu masalah tertentu dan kemudian mencari solusi atau kesimpulan yang terbaik. Working Memory merupakan tempat penyimpanan faktafakta yang diketahui dari hasil menjawab pertanyaan. User/developer interface. Semua software pengembangan sistem pakar memberikan interface yang berbeda bagi user dan developer. User akan berhadapan dengan tampilan yang sederhana dan mudah sedangkan developer akan berhadapan dengan editor dan source code waktu mengembangkan program. Explanation facility memberikan penjelasan saat mana user mengetahui apakah alasan yang diberikan sebuah solusi. External programs. Berbagai program seperti database, spreadsheets, algorithms, dan lainnya yang berfungsi untuk mendukung sistem.

Arsitektur sistem pakar terdiri atas tiga modul utama, yaitu: knowledge base, working memory dan inference engine yang merupakan bagian utama dari sebuah sistem pakar. Sedangkan bagian-bagian selain ketiga komponen utama itu adalah : user interface, developer interface, explanation facility, dan external programs.

Secara umum, beberapa manfaat yang dapat diambil dengan adanya sistem pakar (Kusumadewi, 2003), antara lain: memungkingkan orang awam bisa mengerjakan perkejaan para ahli; bisa melakukan proses secara berulang secara otomatis; menyimpan pengetahuan dan keahlian para pakar; meningkatkan output dan produktivitas; meningkatkan kualitas; mampu mengambil dan melestarikan keahlian para pakar (terutama yang termasuk keahlian langka); mampu beroperasi dalam lingkungan yang berbahaya; memiliki kemampuan untuk mengakses pengetahuan; memiliki reliabilitas; meningkatkan kapabilitas sistem komputer; memiliki kemampuan untuk bekerja dengan informasi yang tidak lengkap dan mengandung ketidakpastian; dan sebagai media pelengkap dalam penelitian.

Dalam penelitian ini dikembangkan bahan perkuliahan dalam bentuk Sistem Pakar agar mahasiswa memiliki kompetensi yang baik, di samping itu juga untuk melatih mahasiswa belajar secara mandiri. Mahasiswa tidak hanya menjadi penerima yang pasif melainkan juga menjadi penentu pembelajaran bagi dirinya sendiri. Pembelajaran yang demikian diharapkan akan memberikan motivasi yang lebih tinggi karena Sistem Pakar selalu dikaitkan dengan kesenangan dan kreativitas. Melalui model bahan ajar yang bersifat interaktif akan membuat mahasiswa belajar tanpa 
beban dan tanpa tekanan karena beragamnya penyajian materi yang menyenangkan sehingga peserta didik termotivasi belajar dengan cepat. Penelitian ini dilaksanakan selama enam bulan. Pada dua bulan pertama, penelitian dilakukan untuk mengidentifikasi kondisi awal dan mengembangkan bahan Sistem Pakar. Pada empat bulan kedua, penelitian dilakukan untuk memvalidasi produk yang meliputi validasi ahli dan validasi pengguna.

Tujuan penelitian ini adalah menghasilkan model Sistem Pakar yang dapat mengembangkan kompetensi dan kemandirian mahasiswa program pendidikan Biologi. Adapun manfaat dari hasil penelitian ini adalah dengan menggunakan Sistem Pakar yang bersifat multimedia dalam proses pembelajaran akan memberikan pengalaman belajar yang bervariasi sehingga merangsang minat peserta didik untuk belajar; menciptakan situasi belajar yang efektif; dan memberikan motivasi belajar kepada peserta didik.

Pengembangan model Sistem Pakar ini penting dilakukan karena beberapa hal berikut. Pertama, ada perubahan budaya belajar mahasiswa dari yang klasikal ke mandiri. Kedua, dapat mengatasi kekurangan bahan dan rujukan bahan ajar sehingga dengan mudah dapat dipahami oleh para mahasiswa. Ketiga, dapat mengatasi kekurangan sumber pembelajaran yang dirancang secara sistematis dengan berpegang pada prinsip-prinsip pengembangan pembelajaran. Keempat, materi pembelajaran berbentuk elektronik akan memudahkan dosen dan mahasiswa dalam proses pembelajaran karena bahan yang dikembangkan tersebut sudah merupakan bahan yang siap pakai. Kelima, berperan dalam mengembangkan diri mahasiswa, terutama untuk mengembangkan potensi dan kemandiriannya. Para mahasiswa dapat mengikuti program pembelajaran sesuai dengan kecepatan dan kemampuan sendiri, lebih banyak belajar mandiri, dan dapat menekankan penguasaan bahan pelajaran secara optimal. Keenam, belajar dalam bentuk Sistem Pakar merupakan bentuk belajar yang efektif dan efisien di zaman sekarang ini, karena harga kertas melambung tinggi dan banyak kemungkinan cepat rusak.

Dalam dunia Biologi, khususnya mengenai hewan, banyak sekali hal yang harus dipelajari agar dapat menghasilkan sesuatu yang bermanfaat. Begitu banyaknya hal yang harus diingat seperti sistem sirkulasi yang berbeda bagi tiap jenis hewan. Tetapi, manusia pasti mempunyai sifat pelupa yang memungkinkan hal-hal tersebut di atas yang akan berakibat pada pemahaman yang kurang memuaskan. Untuk mengatasi hal di atas, salah satunya dibutuhkan suatu teknologi yang dapat membantu permasalahan tersebut.

Oleh karena itu, Sistem Pakar (Expert System) mempunyai kemampuan untuk memudahkan masalahmasalah praktis pada saat sang pakar berhalangan. Banyak sekali yang dibahas pada sistem sirkulasi sehingga membingungkan mahasiswa untuk dapat mempelajarinya. Sistem pakar ini sangat berguna untuk membantu dalam mengingat sistem sirkulasi jenis-jenis hewan juga untuk mengenali ciri-cirinya sehingga dapat meminimalkan kesalahan dalam memahaminya.

Sesuai dengan latar belakang masalah di atas, masalah dalam penelitian ini adalah sebagai berikut pengembangan dan pendesainan model pemrograman Sistem Pakar yang bagaimanakah yang dapat digunakan sebagai bahan ajar tentang Fisiologi Sirkulasi?. Secara umum penelitian ini bertujuan untuk mengembangkan model pembelajaran Fisiologi Sirkulasi berupa pengembangan Sistem Pakar yang dapat digunakan untuk mengoptimalkan pemahaman mahasiswa tentang Fisiologi Sirkulasi. Tujuan tersebut dapat dicapai melalui tahap-tahap, yaitu mengidentifikasi karakteristik Sistem Pakar untuk mengoptimalkan pemahaman mahasiswa tentang Fisiologi Sirkulasi. Mengidentifikasi permasalahan lapangan yang berkaitan dengan bahan ajar, kegiatan pembelajaran, serta pendapat mahasiswa tentang Sistem Pakar.

Adapun urgensi dari penelitian ini adalah bahwa produk perkembangan teknologi informasi yang dapat digunakan dan diterapkan dalam memecahkan kesulitan dalam memahami Fisiologi Sirkulasi adalah Sistem Pakar. Sistem pakar merupakan suatu bentuk sistem yang berusaha mengadopsi ilmu pengetahuan manusia dan diaplikasikan dalam komputer, sehingga komputer memiliki kemampuan dalam menyelesaikan masalah seperti yang dilakukan oleh seorang ahli. Pengemasan produk teknologi informasi dalam merancang suatu aplikasi akan menghasilkan suatu sumber belajar atau bahan ajar yang ekonomis, praktis dan sederhana, fleksibel, relevan, dan dapat digunakan dalam proses pembelajaran.

Oleh karena itu, penelitian ini sangat bermanfaat untuk dilaksanakan dalam rangka mengoptimalkan pemahaman mahasiswa dalam mempelajari Fisiologi Sirkulasi. Selain itu, salah satu tujuan lain dari penelitian ini adalah menerapkan teknologi informasi dalam bidang Biologi untuk mengefektifkan dan mengefisiensikan proses pembelajaran hingga memudahkan dalam mencapai tujuan pembelajaran.

Bagi institusi pendidikan, hasil penelitian ini dapat menambah tersedianya bahan ajar, khususnya dalam matakuliah Fisiologi Hewan yang dapat digunakan baik oleh pendidik maupun peserta didik. Selain itu, hasil penelitian ini akan menambah variasi dalam proses pembelajaran. Lebih lanjut, manfaat penelitian ini adalah berupa pengembangan ilmu dan kontribusi publikasi ilmiah. Para mahasiswa akan banyak belajar dan mendapatkan pengalaman berharga dalam berbagai aspek. Dalam jangka panjang, hasil penelitian ini dapat dijadikan dasar untuk penelitian lebih lanjut baik pada materi ajar Fisiologi Hewan maupun pada materi ajar lainya (multidisiplin) sehingga akan memperkaya khasanah keilmuan di lingkungan pendidikan. Dalam penelitian ini diharapkan menghasilkan suatu model pembelajaran dan suatu aplikasi Sistem Pakar yang dapat diterapkan pada proses pembelajaran di lingkungan pendidikan Biologi dalam mengoptimalkan 
penguasaan mahasiswa tentang Fisiologi Hewan.

\section{BAHAN DAN METODA}

Bahan-bahan yang digunakan dalam penelitian ini adalah: pustaka dan rujukan untuk bahan ajar Fisiologi Sirkulasi yang diambil dari berbagai sumber, perangkat keras, yaitu dalam penelitian ini hardware dan software yang digunakan adalah: 1). Notebook dengan spesifikasi Processor Intel Core i3-350M, RAM DDR3 1GB, Harddisk 500 GB, dan Resolusi Monitor 1366 x 768; 2) Software yang digunakan yaitu : Windows 7 Ultimate dan Visual Prolog v 5.2 Personal Edition for Windows 32, dan software pendukung lainnya.

Secara garis besar peracangan sistem ini dapat digambarkan dalam bentuk konteks diagram sebagai berikut:

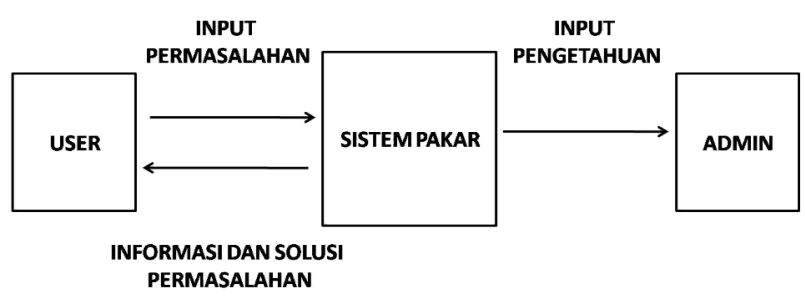

Gambar 3. Diagram perancangan Sistem Pakar

Penelitian ini termasuk pengembangan. Model pengembangan yang digunakan adalah model pengembangan sistem yang mencakup langkah-langkah: studi pendahuluan, perencanaan, pengembangan, dan pengujian produk. Studi pendahuluan meliputi kegiatan mengidentifikasi kebutuhan belajar mahasiswa dan dosen dan mengidentifikasi karakteristik mahasiswa. Perencanaan dan pengembangan produk meliputi kegiatan (1) mengidentifikasi tujuan umum pembelajaran, (2) melakukan analisis pembelajaran, (3) merumuskan tujuan khusus, (4) pengembangan strategi pembelajaran interaktif, dan (5) penyusunan perangkat Sistem Pakar sebagai bahan pembelajaran. Pengujian produk Sistem Pakar dilakukan dengan cara pemberian angket, untuk itu dikembangkan instrumen angket untuk mengumpulkan data analisis dari uji ahli dan uji perorangan terhadap produk Sistem Pakar.

Penelitian ini dirancang dengan desain penelitian Research and Development ( $\mathrm{R}$ and D). Langkah-langkah penelitian yang digunakan sesuai dengan alur kerja pada metode R and D dalam Sugiyono (2010). Tahap proses pengembangan Sistem Pakar yang terdiri atas: analisis potensi dan masalah, pengumpulan data awal, pembuatan produk, validasi produk awal, revisi produk I, uji coba produk I, revisi produk II, uji coba produk II, dan revisi produk III, dan uji produk akhir.

Data dalam penelitian ini dianalisis dengan dua macam teknik. Pertama, data dianalisis secara kualitatif untuk data dari hasil telaah pustaka, angket analisis kebutuhan, dan karakteristik mahasiswa. Kedua, data dianalisis secara kuantitatif untuk data hasil validasi ahli dan perorangan. Teknik yang digunakan untuk menganalisis data validasi ahli dan perorangan adalah statistik deskriptif. Data penelitian didapat dari hasil pengamatan media bahan ajar Fisiologi Sirkulasi produk I, produk II (hasil revisi produk I), dan produk III (hasil revisi produk II). Data berupa penilaian kelayakan bahan ajar oleh para ahli dan mahasiswa. Angket yang diberikan kepada para ahli dan mahasiswa ditentukan penilaiannya, yaitu "A" apabila Sangat Layak, "B" apabila Layak, "C" apabila Cukup Layak, "D" apabila Kurang Layak, dan "E" apabila Tidak Layak, selanjutnya diolah dengan menggunakan rumus persentase menurut Warsito (1992).

Dalam pengembangan ini penulis melakukan eksperimen dalam pengembangan sistem dari berbagai sumber dan menjadi Sistem Pakar untuk sistem sirkulasi dimana nantinya dapat memberikan informasi bagi pengguna komputer yang mengalami permasalahan dalam memahaminya.

Selanjutnya, untuk menilai suatu aplikasi, tentu banyak sekali kriteria yang harus diperhatikan agar dapat mewakili penilaian secara keseluruhan terhadap aplikasi yang dibuat. Barker dan King (1993 dalam Geissinger, 2009) memiliki empat kriteria untuk menganalisis suatu software multimedia, yaitu : 1) Quality of End-User Interface Design, aspek ini menekankan kepada kualitas dari desain tampilan (design) dan kemudahan dalam penggunaannya (easy of use); 2) Engagement, aspek ini menekankan kepada kemenarikan aplikasi yang dibuat, yang mana penggunaan aplikasi secara baik dapat menarik atau meningkatkan motivasi pengguna untuk menggunakan aplikasi yang telah dibuat; 3) Interactivity, aspek ini menekankan kepada bagaimana dalam penggunaan software tercipta suatu interaksi antara pengguna dengan aplikasi, pada aspek ini dilihat bagaimana dalam menjalankan suatu aplikasi, keberfungsian bagian dari aplikasi, dan aplikasi ini dapat benar-benar dijalankan; dan 4) Tailorability, aspek ini menekankan kepada ketersesuaian isi, bagaimana materi ditampilkan, dan keteraksesan isi dalam aplikasi.

Selanjutnya, untuk menganalisis aplikasi yang dibuat digunakan pengujian alpha yang dilakukan untuk mengetahui apakah data yang dimasukan sudah sesuai dengan yang diharapkan dan pengujian beta berupa angket yang diberikan kepada responden yang dilakukan untuk mengetahui respon dan penilaian dari responden terhadap aplikasi yang dibuat, yaitu dengan menggunakan rumus presentase sebagai berikut :

$$
P=\frac{\Sigma}{N} \times 100
$$

Keterangan :

$\mathrm{P}=$ Jumlah presentase setiap pertanyaan

$\Sigma=$ Jumlah responden yang memilih

$\mathrm{N}=$ Jumlah seluruh responden

Adapun klasifikasi interprestasi perhitungan persentase menurut Warsito (1992) yang telah dimodifikasi oleh peneliti sesuai dengan kebutuhan, yang dapat dilihat pada tabel di bawah ini. 
TABEL I

INTERPRETASI HASIL PERHITUNGAN

\begin{tabular}{|c|l|}
\hline Besar Persentase & \multicolumn{1}{|c|}{ Interpretasi } \\
\hline $0 \%$ & Tidak Ada \\
\hline $1 \%-25 \%$ & Sebagian Kecil \\
\hline $26 \%-49 \%$ & Hampir Setengahnya \\
\hline $50 \%$ & Setengahnya \\
\hline $51 \%-75 \%$ & Sebagian Besar \\
\hline $76 \%-99 \%$ & Pada Umumnya \\
\hline $100 \%$ & Seluruhnya \\
\hline
\end{tabular}

Penelitian ini dilakukan sekitar bulan Januari 2016 sampai bulan Juli 2016 di Program Studi Pendidikan Biologi STKIP Garut.

\section{HASIL DAN DISKUSI}

\section{A. Hasil}

Berdasarkan hasil observasi selama di lingkungan Program Studi Pendidikan Biologi STKIP Garut, sebagai sumber bahan ajar dan media pembelajaran yang biasa digunakan adalah buku cetak (textbook) dan media yang memanfaatkan teknologi, seperti media presentasi Microsoft Powerpoint, video pembelajaran, dan media lainnya, namun produk hasil teknologi informasi, yaitu Sistem Pakar belum digunakan. Sistem Pakar ini merupakan produk teknologi informasi, yaitu suatu program komputer yang dirancang untuk memodelkan kemampuan penyelesaian masalah yang dilakukan oleh seorang pakar. Selain itu, metode pembelajaran yang digunakan sebagian besar masih menggunakan metode konvensional.

Selanjutnya, dari hasil observasi dilakukan studi pustaka dan pengumpulan data yang ditindaklanjuti dengan membuat dan mengembangkan produk. Proses pengembangan produk dilakukan secara bertahap, tahap I produk bahan ajar dibuat, setelah divalidasi dan direvisi lanjut pada tahap II. Setelah divalidasi dan direvisi lanjut pada tahap III bahan ajar hasil revisi dibuat dalam format Sistem Pakar.

Adapun kelayakan produk pada setiap tahap divalidasi oleh para ahli dan hasil validasinya dapat dillihat pada Tabel II.

TABEL III

KELAYAKAN PRODUK

\begin{tabular}{|l|l|c|c|c|}
\hline \multirow{2}{*}{ No } & \multirow{2}{*}{ Ahli } & $\begin{array}{c}\text { Penilaian } \\
\text { Tahap I }\end{array}$ & $\begin{array}{c}\text { Penilaian } \\
\text { Tahap II }\end{array}$ & $\begin{array}{c}\text { Penilaian } \\
\text { Tahap III }\end{array}$ \\
\cline { 3 - 5 } & \multicolumn{3}{|c|}{ Kriteria } \\
\hline 1 & Media & $\begin{array}{c}\text { Cukup } \\
\text { Layak } \\
(84,5 \%)\end{array}$ & $\begin{array}{c}\text { Layak } \\
(90,2 \%)\end{array}$ & $\begin{array}{c}\text { Sangat Layak } \\
(92,6 \%)\end{array}$ \\
\hline 2 & Materi & $\begin{array}{c}\text { Layak } \\
(93 \%)\end{array}$ & - & - \\
\hline
\end{tabular}

Terjadi peningkatan kriteria kelayakan mulai tahap I ke tahap II hingga ke tahap III. Peningkatan ini terjadi karena setelah divalidasi dilakukan revisi sesuai saran para ahli.
Sementara itu, untuk ahli materi, validasi cukup dilakukan sekali pada penilaian tahap I saja karena pada penilaian tahap I sudah mendapat persentase 93\%, namun saran atau masukan revisi tetap dilakukan.

Pada validasi tahap I dan tahap II, ahli media dan ahli materi memberikan saran untuk perbaikan, yaitu halaman awal, halaman isi, dan pengemasan bahan ajar. Pada tahap II bahan ajar direvisi kembali dengan menambahkan audio dan gambar untuk halaman awal dan halaman isi, selanjutnya bahan ajar dikemas kembali.

Pada tahap III bahan ajar direvisi kembali dengan mengubah tampilan background dan gambar untuk halaman isi serta penambahan latihan soal. Selanjutnya bahan ajar dikemas menjadi format Sistem Pakar. Setelah dilakukan revisi pada tahap III dihasilkan produk yang siap untuk diuji kelayakannya. Adapun maksud dari Uji kelayakan dilakukan untuk mengetahui keterbacaan dan kesiapan produk. Adapun hasil uji kelayakan keseluruhan pernyataan pada uji coba produk disajikan pada Tabel III.

TABEL IIIII

KELAYAKAN SISTEM PAKAR

\begin{tabular}{|c|c|c|}
\hline Responden & $\begin{array}{c}\text { Jumlah } \\
\text { Mahasiswa }\end{array}$ & Kriteria \\
\hline $\begin{array}{c}\text { Mahasiswa } \\
\text { tingkat III }\end{array}$ & 34 & $\begin{array}{c}\text { Sangat Layak } \\
(87,2 \%)\end{array}$ \\
\hline $\begin{array}{c}\text { Mahasiswa } \\
\text { tingkat III }\end{array}$ & 35 & $\begin{array}{c}\text { Sangat Layak } \\
(88,3 \%)\end{array}$ \\
\hline
\end{tabular}

Setelah diuji kelayakannya, mahasiswa diminta untuk mengisi angket tanggapan tentang Sistem Pakar. Berdasarkan angket tersebut produk akan direvisi sesuai dengan masukan dari para mahasiswa. Tahap revisi akhir ini dilakukan sampai produk dinyatakan layak oleh ahli.

Tahapan berikutnya setelah proses pengembangan adalah uji pemakaian. Pada uji pemakaian, data yang diambil berupa tanggapan mahasiswa. Tanggapan mahasiswa digunakan untuk mengetahui penilaian mahasiswa terhadap produk yang dikembangkan. Data hasil tanggapan mahasiswa yang berupa angket dianalisis dengan teknik deskriptif persentase. Hasil perhitungan tanggapan mahasiswa terhadap Sistem Pakar dapat dilihat pada Tabel IV.

TABEL IVV

RESPON MAHASISWA TERHADAP SISTEM PAKAR

\begin{tabular}{|l|c|c|}
\hline \multicolumn{1}{|c|}{ Kategori } & Persentase & Kriteria \\
\hline $\begin{array}{l}\text { Quality of end-user } \\
\text { interface design }\end{array}$ & 56,24 & Layak \\
\hline Engagement & 64,90 & Sangat Layak \\
\hline Interactivity & 63,90 & Sangat Layak \\
\hline Tailorability & 52,29 & Layak \\
\hline
\end{tabular}

Hasil studi pendahuluan menunjukkan beberapa masalah yang dijumpai dalam pembelajaran, antara lain bahan pembelajarannya yang banyak dan padat sehingga beban belajar mahasiswa menjadi sangat banyak, model pembelajaran yang monoton, yaitu dominan penjelasan 
dosen, pembelajaran tidak banyak memanfaatkan media pembelajaran sehingga kurang ada variasi, kurang adanya umpan balik terhadap tugas yang telah dikerjakan oleh mahasiswa. Berdasarkan kondisi ini, secara umum mahasiswa berpendapat bahwa memang perlu dikembangkan bahan pembelajaran interaktif yang banyak melibatkan mereka dalam pembelajaran, dan mengurangi peran dosen yang sangat dominan. Hal ini sesuai dengan pendapat Gebhard (2000:53), bahwa salah satu faktor yang mendukung terciptanya aktivitas pembelajaran yang interaktif, yaitu adanya pengurangan peran sentral pengajar. Namun demikian, kehadiran dosen masih sangat diperlukan oleh mahasiswa, sehingga pembagian peran dosen dan materi menjadi jelas. Sikap, minat, dan motivasi mahasiswa secara umum dalam belajar cukup baik, hal ini akan sangat menunjang berhasilnya produk yang akan dikembangkan. Menurut Dick and Carey (1990), seorang pengembang perlu mengenali ciri-ciri khusus tertentu yang dimiliki mahasiswa yang memang perlu dipertimbangkan dalam merancang kegiatan-kegiatan pembelajaran. Menurut Sadiman (1996:103), dengan melakukan identifikasi karakteristik mahasiswa, berarti akan diketahui pengetahuan dan keterampilan awal mereka sebelum mengikuti kegiatan pembelajaran dengan bahan yang akan dikembangkan. Data yang terkumpul dari kegiatan analisis kebutuhan dan identifikasi karakteristik mahasiswa ini selanjutnya digunakan sebagai dasar dalam perencanaan dan pengembangan produk.

Pada perencanaan produk, langkah pertama yang dilakukan adalah menentukan tujuan umum pembelajaran. Tujuan umum ini dirumuskan dari Satuan Acara Perkuliahan (SAP) dan hasil studi pendahuluan. Dalam setiap tujuan dirumuskan menjadi beberapa tujuan khusus sejalan dengan analisis pembelajaran yang telah dikembangkan. Pembelajaran dengan Sistem Pakar tetap menganggap kehadiran dosen penting. Oleh karena itu, pembelajaran dirangcang dengan baik dengan tetap melibatkan kegiatan dosen dan mahasiswa. Strategi interaktif dipilih karena sesuai dengan produk yang dikembangkan, yaitu Sistem Pakar. Pada pengembangan strategi pembelajaran ini disusun langkah-langkah pembelajaran mulai awal hingga akhir perkuliahan, yang dikembangkan dengan prinsip pembelajaran komunikatif.

Berdasarkan hasil langkah-langkah perencanaan produk, selanjutnya dilakukan proses penyusunan draf perangkat produk yang akan dikembang, yang meliputi panduan dosen, petunjuk mahasiswa, dan bahan pembelajaran. Panduan Dosen berisi arahan kepada dosen pengampu matakuliah bagaimana menggunakan produk yang dikembangkan. Petunjuk mahasiswa berisi arahan kepada mahasiswa bagaimana cara menggunakan produk dan berisi tentang pokok-pokok bahasan yang harus dipelajari.

Produk akhir yang dihasilkan dari proses pengembangan ini adalah Sistem Pakar. Produk ini berisi sejumlah bahan materi perkuliahan yang dikemas dalam format SWF. Sistem Pakar ini dikembangkan dengan bantuan beberapa perangkat lunak. Selain disusun dengan software yang tepat, bahan dalam Sistem Pakar ini ditata sedemikian rupa agar materi mudah dikuasai oleh mahasiswa. Uraian materi yang disusun cukup rinci, dan diakhiri dengan latihan interaktif berupa latihan yang dikerjakan secara langsung oleh mahasiswa saat itu juga.

Validasi produk yang dihasilkan meliputi: validasi ahli media, ahli materi, dan mahasiswa sebagai pengguna. Menurut ahli media dan ahli materi, secara umum aspek produk penelitian yang dikembangkan sudah layak. Ini berarti, Sistem Pakar yang dikembangkan layak digunakan dalam pembelajaran. Rancangan dan multimedia yang dikembangkan sudah memenuhi persyaratan media pembelajaran yang baik. Secara kelompok maupun perorangan, mahasiswa sangat menyetujui (Layak dan Sangat Layak) untuk semua pernyataan yang dikemukakan dalam angket. Ini berarti, mahasiswa sangat sangat senang, faham, dan mudah menggunakan produk penelitian ini.

Analisis tanggapan mahasiswa terhadap Sistem Pakar untuk setiap kategori menurut Baker dan King (1993 dalam Geissinger, 2009) adalah sebagai berikut: 56,24\% pengguna menilai untuk kategori Quality of end-user interface design dalam kategori baik. Geissinger (dalam Prasetyawan, 2010) mengungkapkan bahwa untuk menciptakan produk yang berkualitas baik dari segi tampilan haruslah memiliki komposisi warna yang tepat, huruf yang sesuai, bahasa yang mudah untuk dipahami, dan button yang memfasilitasi dalam penjelajahan produk. Untuk kategori Engagement, $64,90 \%$ pengguna menilai produk berada dalam kategori sangat baik, Geissinger (dalam Prasetyawan, 2010) mengungkapkan bahwa untuk menciptakan produk yang berkualitas baik harus didukung oleh tampilan grafis yang terlihat, sehingga membuat informasi menjadi lebih atraktif, mudah diingat, dan mudah dipahami. Untuk kategori Interactivity, 63,90\% pengguna menilai produk berada dalam kategori sangat baik, Geissinger (dalam Prasetyawan, 2010) mengungkapkan bahwa untuk menciptakan produk yang berkualitas baik dari segi kualitas teknis harus memiliki kemudahan dalam menjalankan aplikasi, pengguna mampu mengoperasikan produk dan tidak merasa jenuh, juga memiliki fasilitas yang cukup untuk menjelajah produk. Untuk kategori Tailorability, 52,29\% pengguna menilai produk berada dalam kategori baik, hal ini berarti ketersesuaian isi pada produk yang dibuat berada dalam kategori baik.

\section{B. Diskusi}

Hasil studi pendahuluan menunjukkan, mahasiswa lebih menyenangi perkuliahan yang banyak melibatkan dirinya dalam pembelajaran sehingga perlu dikembangkan bahan pembelajaran yang interaktif. Perencanaan dan pengembangan produk meliputi kegiatan mengidentifikasi tujuan umum pembelajaran, melakukan analisis pembelajaran, merumuskan tujuan khusus, pengembangan strategi pembelajaran interaktif, dan penyusunan perangkat Sistem Pakar yang dirancang secara sistematis dengan berpegang pada prinsip-prinsip pengembangan pembelajaran. Hasil uji validasi produk, menurut ahli media 
dan ahli materi secara umum aspek produk penelitian yang dikembangkan sudah layak.

Sedangkan validasi pengguna, secara umum mahasiswa sangat senang, mudah memahami, dan mudah mengoperasikan Sistem Pakar. Tanggapan mahasiswa terhadap produk Sistem Pakar untuk kategori Quality of end-user interface design termasuk dalam kriteria baik (56,24\%), kategori Engagement termasuk dalam kriteria sangat baik $(64,90 \%)$, kategori Interactivity termasuk dalam kategori sangat baik $(63,90 \%)$, kategori Tailorability termasuk dalam kriteria baik (52,29\%). Secara keseluruhan, hasil penelitian menunjukan bahwa Sistem Pakar dapat diterapkan dan layak digunakan sebagai media pembelajaran Fisiologi Saraf untuk mahasiswa Pendidikan Biologi.

Seperti diketahui, pemanfaatan teknologi dalam pembelajaran (TP) merupakan sebuah upaya inovatif untuk mempercepat peningkatan kualitas pembelajaran. Menurut Seels dan Richey (dalam Warsita, 2008: 13) menyebutkan bahwa teknologi pembelajaran adalah teori dan praktik dalam desain, pengembangan, pemanfaatan, pengelolaan, serta evaluasi tentang proses, dan sumber untuk belajar.

Darmawan (2015: 4) menyatakan bahwa lembagalembaga pendidikan sudah selayaknya segera memperkenalkan dan memulai menggunakan teknologi informasi dan komunikasi sebagai basis pembelajaran yang lebih mutakhir. Hal ini penting, mengingat penggunaan TIK merupakan salah satu faktor penting yang memungkinkan kecepatan transformasi ilmu pengetahuan kepada para peserta didik, generasi bangsa ini secara lebih luas.

Selanjutnya Silber (dalam Warsita, 2008: 15) menyatakan bahwa Teknologi Pembelajaran adalah pengembangan (riset, desain, produksi, evaluasi, dukungan-pasokan, dan pemanfaatan) komponen sistem pembelajaran (pesan, orang, bahan peralatan, teknik, dan latar) serta pengelolaan usaha pengembangan (organisasi dan personal) secara sistematis, dengan tujuan untuk memecahkan masalah belajar.

Oleh karena itu, Teknologi Pembelajaran (TP) merupakan upaya inovasi dalam bidang pendidikan dan pembelajaran. Dengan penguasaan dan penggunaan TP oleh para pendidik dan mahasiswa sangat memungkinkan percepatan pencapaian kualitas pendidikan dan pembelajaran karena TP merupakan sebuah solusi yang dapat memecahkan kesulitan belajar siswa. Perkembangan TP juga memungkinkan perubahan kualitas model-model pembelajaran yang telah ada.

Berdasarkan hasil observasi dalam penelitian ini dilakukan selama berlangsungnya pembelajaran. Observasi ini dilakukan untuk mengetahui bagaimana respon yang diberikan oleh siswa terhadap penggunaan Sistem Pakar dalam pembelajaran, keaktifan mahasiswa dan juga untuk mengetahui kekurangan-kekurangan selama terjadinya proses pembelajaran dengan menggunakan Sistem Pakar.

Sejak awal mengetahui akan menggunakan Sistem Pakar dalam proses pembelajaran siswa sudah sangat bersemangat karena ini adalah hal yang baru bagi mereka. Para siswa asyik menggali fitur-fitur yang disediakan dalam aplikasi
Sistem Pakar yang mereka gunakan. Selama proses pembelajaran mahasiswa menjadi lebih fokus terhadap materi dalam Sistem Pakar dan sesekali bertanya mengenai bagian-bagian yang tidak mereka mengerti.

Secara umum, mahasiswa berperan aktif dalam kegiatan pembelajaran. Hal ini disebabkankan oleh penggunaan Sistem Pakar membuat mereka lebih tertarik dan penasaran dengan aplikasi yang digunakan. Seperti kita ketahui, saat ini Sistem Pakar belum umum digunakan oleh para mahasiswa. Maka, penggunaan Sistem Pakar merupakan salah satu pendekatan yang efektif untuk menyampaikan konten pendidikan dengan cara yang lebih menarik, inovatif dan menyenangkan bagi para siswa.

Pembelajaran merupakan suatu kegiatan yang melibatkan seseorang dalam upaya memperoleh pengetahuan, keterampilan dan nilai-nilai positif dengan memanfaatkan berbagai sumber untuk belajar (Susilana, 2007 : 1). Di lain pihak Ariani dan Haryanto (2010 : 25) mengartikan bahwa pembelajaran merupakan proses pencipataaan lingkungan yang memungkinkan terjadinya proses belajar. Jadi dalam pembelajaran yang utama adalah bagaimana siswa belajar, dalam arti siswa secara aktif berinteraksi dengan lingkungan dan berbagai sumber belajar yang ada, sehingga menghasilkan perubahan perilaku sebagai hasil belajar.

Kaitannya bahwa belajar membutuhkan interaksi, hal ini menunjukan bahwa proses pembelajaran merupakan proses komunikasi, artinya di dalamnya terjadi proses penyampaian pesan dari seseorang (sumber pesan) kepada seseorang atau sekelompok orang (penerima pesan). Pesan yang dikirimkan biasanya berupa informasi atau keterangan dari pengirim (sumber) pesan. Pesan tersebut diubah dalm bentuk sandisandi atau lambang-lambang seperti kata-kata, bunyi-bunyi, gambar dan sebagainya.

Untuk membantu penyampaian pesan dalam komunikasi atau interkasi tersebut di atas, diperlukan saluran berupa media pembelajaran. Media pembelajaran merupakan bagian dari sebuah proses komunikasi atau interaksi dalam proses pembelajaran, untuk menyampaikan isi, materi atau topik pembelajaran. Susilana dan Riyana (2007 : 4) mengemukakan bahwa bentuk komunikasi pembelajaran manapun akan memperolah tingkat efektifitas pencapaian tujuan/kompetensi belajar, jika melibatkan peran media pembelajaran di dalamnya.

Secara umum manfaat yang dapat diperoleh dalam kegiatan pembelajaran berbasis multimedia adalah proses pembelajaran jelas lebih menarik, lebih interaktif, jumlah waktu mengajar (ceramah) bisa dikurangi, kualitas belajar siswa lebih termotivasi, kegiatan pembelajaran dapat dilakukan kapan saja dan dimana saja (sangat fleksibel) serta sikap dan perhatian belajar siswa dapat ditingkatkan dan dipusatkan.

Sistem pengajaran berbasis multimedia dapat menyajikan materi pelajaran yang lebih menarik, tidak monoton dan memudahkan penyampaian. Siswa dapat mempelajari materi tertentu secara mandiri dengan menggunakan komputer yang dilengkapi dengan program berbasis multimedia. Hasil-hasil penelitian tentang pembelajaran 
berbantuan komputer dirangkum oleh Sherwood (1991), yaitu pembelajaran dengan komputer dapat: (1) mempermudah siswa dalam memperoleh informasi dan mempermudah guru dalam menyampaikan permasalahan yang kontekstual kepada siswa, (2) meningkatkan kepercayaan diri, kemampuan, dan pengetahuan siswa untuk memecahkan permasalah, menjadi pemikir dan pelajar yang independen, (3) dilihat secara visual, dinamis, dan tiga dimensi sehingga merupakan model mental yang kaya informasi sehingga memudahkan siswa dalam memahami konsep, terutama konsep-konsep yang abstrak dan bersifat proses, dan dalam memecahkan masalah. Darmawan (2015:38) menyebutkan bahwa pembelajaran interaktif berbasis komputer mampu mengaktifkan siswa untuk belajar dengan motivasi yang tinggi karena ketertarikannya pada sistem multimedia yang mampu menyuguhkan tampilan teks, gambar, video, suara, dan animasi.

Model pembelajaran berbasis teknologi pada saat ini merupakan salah satu model pembelajaran yang sudah sepatutnya dikuasai oleh dosen karena media merupakan alat untuk mempermudah proses pembelajaran dan mahasiswa dapat belajar secara mandiri. Dalam dunia kependidikan, guru saat ini selain selain harus menguasai disiplin keilmuannya juga dituntut menguasai model pembelajaran yang tepat agar tujuan pembelajaran tercapai secara efektif.Sistem Pakar telah mengembangkan proses pembelajaran ke arah yang lebih dinamis. Terlebih lagi yang paling penting adalah berkualitasnya pemahaman tentang bagaimana menggunakan teknologi tersebut dengan lebih efektif dan dapat menghasilkan pemikiran-pemikiran baru bagi kemajuan pembelajaran. Pada saat ini dosen perlu memiliki kemahiran dalam menggunakan teknologi dengan cara yang paling bermakna bagi pembelajaran. Proses pembelajaran yang interaktif dapat membangkitkan komunikasi yang aktif dalam berbagai hal dengan tujuan meningkatkan mutu pembelajaran.

Manfaat tersebut dapat dengan mudah direalisasikan mengingat terdapat beberapa keunggulan yang diperoleh dalam kegiatan pembelajaran berbasis Sistem Pakar. Tak dapat dipungkiri bahwa teknologi Sistem Pakar mampu memberi manfaat dan dampak besar dalam komunikasi dan pendidikan karena bisa mengintegrasikan teks, grafik, dan audio, serta mengembangkan proses belajar ke arah yang lebih dinamis. Lebih jauh sistem belajar dengan menggunakan Sistem Pakar memungkinkan sekolah-sekolah yang letaknya terpencil memiliki kesempatan menikmati pembelajaran yang mutunya tak kalah dengan yang ada didaerah perkotaan.

\section{KESIMPULAN DAN SARAN}

Hasil studi pendahuluan menunjukkan, mahasiswa lebih menyenangi perkuliahan yang banyak melibatkan dirinya dalam pembelajaran sehingga perlu dikembangkan bahan pembelajaran yang interaktif. Perencanaan dan pengembangan produk meliputi kegiatan mengidentifikasi tujuan umum pembelajaran, melakukan analisis pembelajaran, merumuskan tujuan khusus, pengembangan strategi pembelajaran interaktif, dan penyusunan perangkat Sistem Pakar yang dirancang secara sistematis dengan berpegang pada prinsip-prinsip pengembangan pembelajaran. Hasil uji validasi produk, menurut ahli media dan ahli materi secara umum aspek produk penelitian yang dikembangkan sudah layak. Sedangkan validasi pengguna, secara umum mahasiswa sangat senang, mudah memahami, dan mudah mengoperasikan Sistem Pakar. Tanggapan mahasiswa terhadap produk Sistem Pakar untuk kategori Quality of end-user interface design termasuk dalam kriteria baik $(56,24 \%)$, kategori Engagement termasuk dalam kriteria sangat baik $(64,90 \%)$, kategori Interactivity termasuk dalam kategori sangat baik $(63,90 \%)$, kategori Tailorability termasuk dalam kriteria baik (52,29\%). Secara keseluruhan, hasil penelitian menunjukan bahwa Sistem Pakar dapat diterapkan dan layak digunakan sebagai media pembelajaran Fisiologi Saraf untuk mahasiswa Pendidikan Biologi.

Peneliti merekomendasikan beberapa hal untuk dijadikan bahan pertimbangan dan pemikiran. Pertama, aplikasi Sistem Pakar merupakan salah satu alternatif media pembelajaran interaktif yang dapat mengembangkan sikap aktif dan mandiri, maka sebaiknya aplikasi Sistem Pakar dapat digunakan untuk setiap materi pada matakuliah lainnya sebagai solusi inovatif untuk mengatasi permasalahan dan kesulitan mahasiswa dalam proses pembelajaran. Kedua, untuk penelitian lebih lanjut, sebaiknya penelitian dilakukan untuk mengukur semua aspek kemampuan mahasiswa, meliputi aspek kognitif, afektif, dan psikomotorik, supaya dapat dilihat bahwa aplikasi Sistem Pakar ini sangat sesuai untuk diterapkan dalam upaya meningkatkan pemahaman mahasiswa. Ketiga, Sistem Pakar sebaiknya dikembangkan agar dapat menangani permasalahan mahasiswa dalam proses belajar secara menyeluruh, bukan hanya sebatas materi Fisiologi Saraf.

\section{PustakA}

[1] Hermawan Warsito, Pengantar Metodologi Penelitian. Jakarta: Gramedia, 1992.

[2] Warsita, Teknologi Pembelajaran, Landasan dan Aplikasinya. Jakarta: Rineka Cipta, 2008.

[3] Sugiyono, Metode Penelitian Kuantitatif Kualitatif dan R\&D. Bandung: Alfabeta, 2010.

[4] Sherwood, "The Develovment and Preliminary Evaluation of Anchored Instruction Environment for Developing Mathematical and Scientific Thinking," in The National Association for Research in Science Teaching, Lake Geneva, 1991.

[5] A Sadiman, Media Pendidikan. Jakarta: Raja Grafindo Persada, 1996.

[6] Ahmad Rohani, Pengelolaan Pengajaran. Jakarta: PT Rineka Cipta, 2004.

[7] Susilana Riyana, Media Pembelajaran. Bandung: CV Wacana Prima, 2011.

[8] Yanuar Yoga Prasetyawan, "Pengaruh Penerapan Sistem Informasi Perpustakaan Terhadap Kualitas Layanan Perpustakaan di Fakultas Ekonomi Universitas Dipenogoro Unit S1 Reguler," Universitas Dipenogoro, Semarang, Skripsi 2010.

[9] Sri Kusumadewi, Artificial Intelligence Teknik dan Aplikasinya. Yogyakarta: Graha Ilmu, 2003.

[10] Kusuma, "E-learning dalam Pembelajaran Bahasa," Lentera Pendidikan, vol. XIV, no. 1,2011 
[11] E.R Kaur, "Importance of Experts System used in Agricultural," International Journal of Enhanced Research in Science Technology and Engineering, vol. 3, no. 5, pp. 265-269, May 2014.

[12] H Geissinger. Educational Software: Criteria for Evaluation. [Online]. www.ascilite.org.au/conferences/perth97/papers/Geissinger/Geissinger.ht $\mathrm{ml}$, [diakses tanggal 15 Februari 2015].

[13] J.G Gebhard, Teaching English as a Foreign or Second Language: A Teacher Self-development and Methodology Guide. Michigan: The University of Michigan Press, 2000.

[14] Turban Efraim, Decesion Support and Expert Systems.: Prentice-Hall International, 1995.

[15] W Dick and L Carey, The Systematic Design of Instruction. London, England: Scat Foresman \& Company, 1990.

[16] Deni Darmawan, Teknologi Pembelajaran. Bandung: PT Remaja Rosda Karya, 2015.

[17] Deni Darmawan, Teknologi Pembelajaran. Bandung: Remaja Rosdakarya, 2011

[18] N dan Haryanto, D Ariani, Pembelajaran Multimedia di Sekolah Pedoman Pembelajaran Inspiratid, Konstruktif dan Prospektif. Jakarta: Prestas Pustaka, 2010.

[19] Muhammad Arhami, Konsep Dasar Sistem Pakar. Yogyakarta: Andi Offset, 2005.

[20] Munir, Kurikulum Berbasis Teknologi Informasi. Bandung: PT Alfabeta, 2010 